\title{
INVOLVEMENT AND TRUST IN POLAND AND BULGARIA IN COMPARISON WITH OTHER EUROPEAN SOCIETIES
}

\author{
Marek Nowak ${ }^{1}$, Piotr Jabkowski ${ }^{2}$, Patryk Borowiak ${ }^{3}$ \\ e-mail:marek.nowak@amu.edu.pl,e-mail:pjabko@amu.edu.pl, \\ e-mail:patryk@amu.edu.pl
}

\begin{abstract}
A developmental analysis of the two waves: 2008 and 2016 ESS Indicators of social engagement (we mean here organisational engagement) are treated as a measure of the process of social modernisation (Herrmann, 1999, Matei, Apostu, 2012). It is assumed here that higher scores of indicators demonstrate the 'maturity of civil society, the quality of the functioning of democracy and the process of its evolution (Boulding, 2010). The concept of generalised trust and trust in political institutions have a somewhat similar status, and they are treated as indicators of collective capacity and a premise for conclusions about the effectiveness of the development processes (Putnam, 1993, Sonderskov, 2011). The proposed presentation will focus on the changes we were able to register over eight years in Poland and Bulgaria (2008 and 2018) to indicate the position of the societies of these post-communist countries in comparison to other European countries. The main hypotheses would be to verify the relationship between trust indicators and declared involvement in NGO sector organisations as well as basic sociodemographic variables in a temporal perspective. The quantitative analysis will be preceded by a form of qualitative description and interpretation of the existing state of knowledge. ESS data would be used for the analysis, and the basis for inference will be the indices of "generalised trust", "trust in national political institutions", and "involvement in NGO” using regression analysis.
\end{abstract}

Key words: generalised trust, trust in national political institutions, organisational involvement in NGO

JEL: O1

\section{Introduction}

The issues of trust and social activism increased in importance along with the recognition of institutional conditions that determine the success of the development of individual organisations and entire societies (North, 1984,

\footnotetext{
${ }^{1}$ AMU Prof., Faculty of Sociology, Adam Mickiewicz University, Poznan

2 AMU Prof., Faculty of Sociology, Adam Mickiewicz University, Poznan; Centre for Critical Social Research

${ }^{3} \mathrm{PhD}$, Faculty of Polish and Classical Philology
} 
1992). The now-classic analyses of institutionalists and economic historians from the 1980s and 1990s suggested a direct translation of the propensity for the unconstrained activity or generalised trust into economic parameters (the amount of the so-called transaction costs that determined the effectiveness of management). These, in turn, contributed to developmental differences in the long run.

Answering questions about why the centres of economic growth shifted - most often within Europe and most often from south to north - allowed generalisations to be made per analogy. It even justified the profound differences in development and living standards by the deregulation of economies and cultural specificity. This referred in sociology to Weberian thinking on development attributed to the dominant ethic. Analyses of key researchers linked the specificity of social ties, writing their evolution into a developmental continuum (distinguishing: bridging, and bounding, where the so-called "weak" ties turned out to be more effective in building social relations, implementing economic projects than the so-called "strong" ties, Putnam 2000). In other words and based on empirical studies, we mean here the evolution of value systems, which are more predestined to describe the transition from materialist to post-materialist values (Inglehart, 2007). Trust has become a key element in reflections on subjectivity, understood as the ability to transform one's environment (Sztompka, 1997, 2007). It combined the modernising tendencies of most developed societies (and thus systemic relations) with an increasingly individualistic perspective on society as itself.

More detailed research indicated that economic issues were the primary determinant of trust levels. Lack of trust was accompanied by more unsatisfactory performance in terms of meeting needs, more precisely: feelings about the level of satisfying needs. As Wroe elaborates in his article: "low trust is driven by economic underperformance. This can be theorised and measured as actual, objective performance and/or perceptions of performance. While objective performance and perceptions both matter, the research base demonstrates that perceptions of economic performance are generally more important than objective performance" (Wroe, 2014, p. 91). In the form of a generalising hypothesis, it can be suggested that the realm of pervasive beliefs plays an essential role in the phenomenon of trust. Trust is as much a domain of the same action of individuals and its outcomes as it is of the cultural interpretative framework.

It is no coincidence that the modes of thinking and empirical observations presented here have remained in convergence with the dominance of neoliberalism in politics, which has been observed in Western Europe since the 1980s, and in Central and South-Eastern Europe since the 1990s. What has remained after the optimistic and, at the same time, the market-oriented perspective of the 1980s and 1990s and two decades of the new millennium, is the awareness that the 
specificity of the historically constructed social order and historically shaped social relations may have a significant impact on the direction of societies' evolution. Parameters such as declared trust, declarations of social involvement in organisations, or attitudes towards public authorities allow to lay hold of causal relations. Moreover, based on polling surveys (conducted cyclically and based on similar tools), they allow to capture the turn of social change, understood as moving towards modernisation (Matei, Apostu, 2012). What is worth emphasising in the convention of the meta-narrative of science is the fact that discussions concerning the spheres of non-market activity and social activism remained in a way parallel to the developed reflection on the factors of economic development. What seems essential, along with the critique of mainstream economism (and in terms of "post-autistic economics", Fullbrook, 2003; Miłaszewicz, 2016), is the idea that they became intertwined, associating the 'lyrical vision' of civic subjectivity, which is always expected and positive (Pluciński, 2006), with pursuing economic interests, which is a source of prosperity.

The condition for an increasingly subjective and at the same time contractual society is in particular:

- trust - that provides support for the operation of institutions;

- trust in others - that they will fulfil their mutual obligations without engaging a 'Hobbesian Leviathan'. Based on cultural similarity.

Regardless of a certain distance from the ideology of neoliberal marketisation of the 1990s, the most contemporary diagnoses show that research data can confirm a link between growth drivers and declarative trust and social activism. According to the authors, this demonstrates not so much the obviousness of the relationship based on an empirically verified trajectory, but rather specific cases that either confirm or contradict the general thesis. Still, the potential for a selffulfilling prophecy (Stukas, Snyder, 2016) is contained in the thinking presented. If one were to treat post-communist Europe as a case study, those mentioned above 'self-fulfilling prophecy' would not radically translate into a levelling off of economic development (as measured by the level of wealth of societies) and an associated radical increase in trust. However, a significant economic growth was noticeable in the rise in living standards measured by the growth of the gross domestic product in purchasing power units (GDP by PPS) and when we observe the dynamics of GDP growth in comparison with European societies. 
Marek Nowak, Piotr Jabkowski, Patryk Borowiak

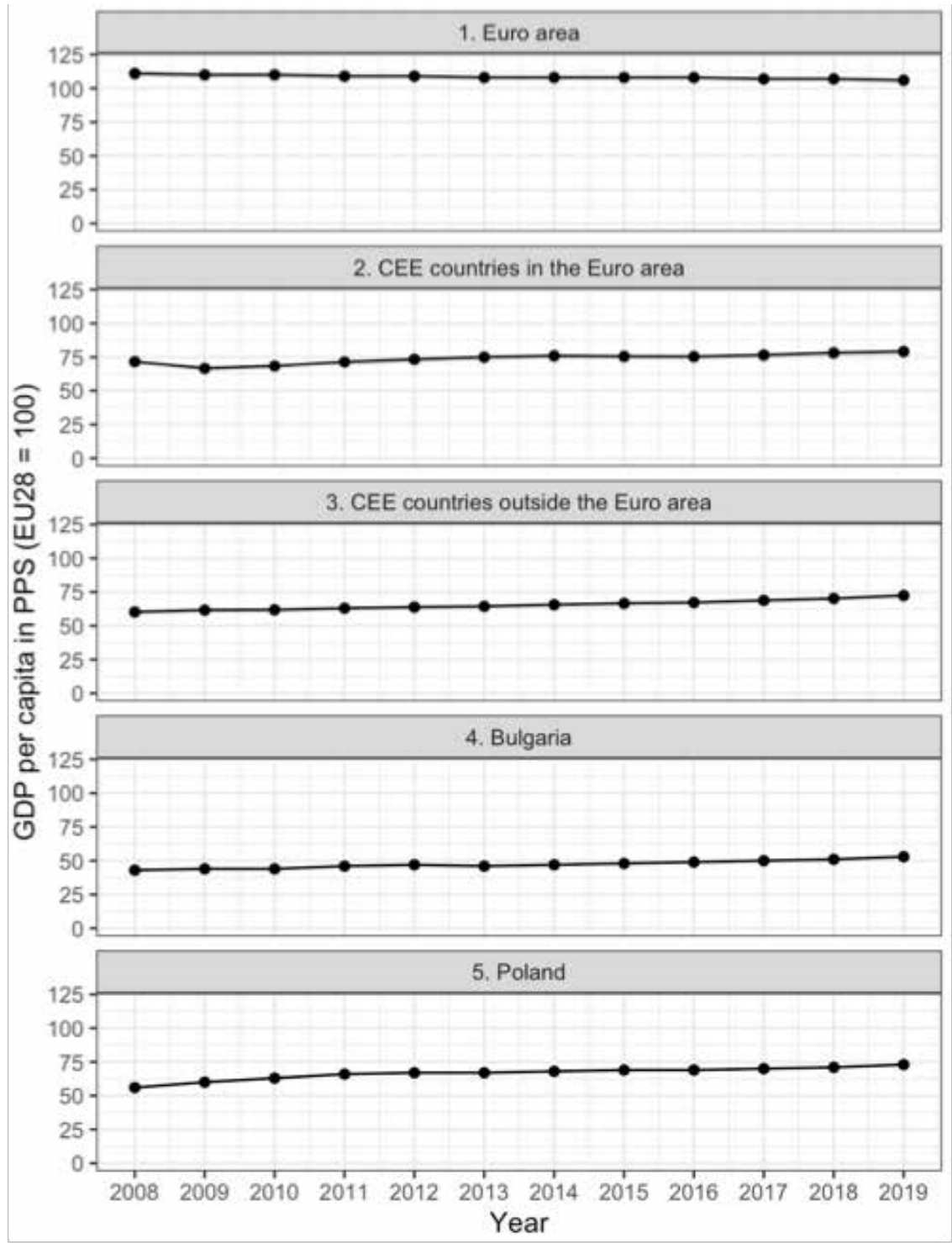

Source: Eurostat (2021) and own elaboration

Figure 1: GDP by PPS, years 2008 (1) - 2016 (12)

This makes possible, at least to some extent, to come close to verifying the hypothesis on factors that were considered as the attribute of influencing social change or as an explanatory variable at the level of analysis of development factors. At the same time, it should be noted that trust is one of such phenomena 
which, when systematically examined, still clearly differentiates European societies. Central and South-Eastern Europe are characterised by a differentiated and somewhat lower level of trust interpreted in macro-social (systemic, Eurostat data presented below) terms. This is particularly visible concerning Central European countries and assessments of confidence in the legal system (Poland, Czechia, Slovakia). We can also observe low trust in the political system. This is otherwise a quite common regularity in Europe (as suggested by the average value). Even lower indices concern selected countries of South-Eastern Europe: Bulgaria, Slovenia; simultaneously, a higher index can be observed in Romania. Significantly, higher indicators concern trust in others (relations of the interactive type or generalised trust); here, the post-communist societies are characterised by indicators closer to the EU28 average.

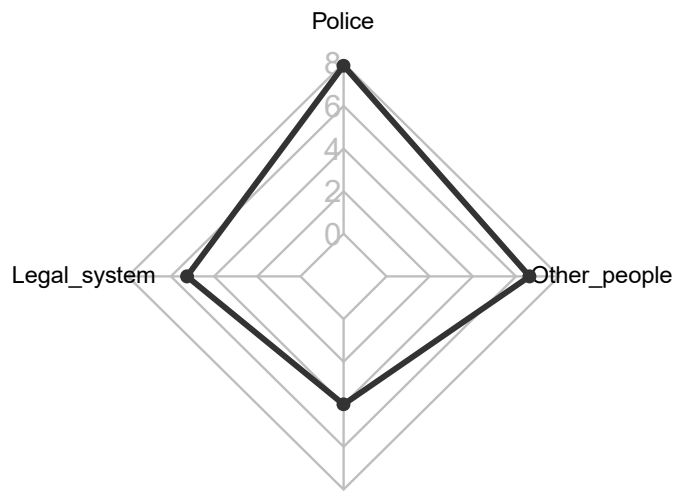

Political_system

Source: Eurostat (2013) and own elaboration

Figure 2: Average rating of trust by domain, sex, age and educational attainment level

We will treat the Eurostat data referred to above as part of a diagnostic framework and a tool for sketching the context. Against their background, data on trust concerning engagement will therefore be interpreted based on the European Social Survey.

\section{Conceptualising trust and activism, the state of the art of research and clarifying the aims of the analysis}

Piotr Sztompka defines trust as "a bet made on people's uncertain, future action" (Sztompka, 2006, p. 69). What is interesting in the proposed definition is the word "bet" implying the image of a strategic game and reduction of trust 
to relations of dual character: (i) an interactive character - the triad model - of cooperating subjects and society, or (ii) a neo-functional character - the dyad model - of the relationship between the subject and the society as a whole. This brings the understanding of trust closer to the two dimensions that the same author formulated in an earlier publication. And these were: "basic trustfulness" and culturally generated trust (Sztompka, 1997, p. 8). The former extends the individual trust attitude to a broader category of people (the abovementioned triad). At the same time, the latter is closer to the concept of trust, referring to cultural sociology, which is present, e.g. in the Chicago School. In the understanding adopted by the authors, the meaning of the notion is broadened to include systemic and, to some extent depersonalised, relations. Trust, based on theoretical assumptions adopted in the article, is the following: occurring in the collective life of a given community, widespread beliefs concerning the possibility of effective realisation of goals.

At the operational level, it is assumed that the notion of trust is related to the declared sense of empowerment (measured on a scale), regardless of the sphere of activity concerned: cooperative relations, the sphere of politics and power, or security. The proposed understanding of trust can be described as "institutional" (Rothstein, Stolle, 2008), in the sense of a specific normative framework within which individual subjectivity is realised. It is only partly attributed - after Piotr Sztompka - to the turn towards culturalism (Sztompka, 2006, pp. 42-45). In part, it is treated - after Giddens, Tilly (Tilly, 2005), or Habermas - as an aspect of the concept of action, which is a derivative of the form of communication and the social conditions in which action takes place. The conceptualized viewpoint constitutes a change in the way of thinking about action, the course of which is no longer dictated solely by the rational or subjectively rational expectation of results by the acting subject. It is an aspect of the collective culture and a consequence of the context of social cooperation. A feature of this culture is that it plays the role of a "toolbox" for resilience in the face of exogenous influences (Swidler, 1986), such as systemic transformation, the crisis of 2008, the increase in inequality, or the current pandemic. Still, it is also a tool for the innovative adaptation of individuals.

What seems central to the concept of trust are four assumptions:

1. The assumption that culture is relatively persistent and is, therefore, an aspect of social continuity and a frame within which change occurs.

2 . The assumption that trust is a mirror image of the simultaneously diagnosed systemic growing complexity and the chaotic world (cf. Beck's classic concept from the 1980s, Beck, 1992). As the author himself puts it: "Trust becomes an indispensable strategy of dealing with the untransparency of the social environment" (Sztompka, 2006, p. 48). 
3. The assumption that subjective actions in terms of the Habermasian 'lifeworld' (Gerard, 1991) remain related to the level of trust in others and the system (culture of trust);

4. The assumption of the differentiation of types of trust and, in practice, the differentiation of the spheres to which trust applies matter. These trust types have a more or less competitive character (Uslaner, Brown, 2003).

The fourth assumption suggests that the article adopts the conditional model of trust, assuming: "there is no necessary incompatibility between particular and general social trust, and that the two may be positively associated in some cases, but not necessarily in most or all cases" (Newton, Zmerli, 2011, p. 175), which implies reinforcing aspects of cultural and situational specificity in the inference. Thus, the concept of trust fills, in a specific cultural-situational way, a gap in the model of social action (from individual needs, through action, to the satisfaction of needs). It connects human values and interests with the concept of functioning under increasing uncertainty. It is, within certain conditions, a "lubricant" or a catalyst for action both in the political sphere and in the economic sphere, because it is necessary to believe that individual effort, which turns out to be actionoriented towards others (when it ceases to be only a declaration), will achieve its goals. As Sztompka suggests the "culture of trust" "liberates and mobilises human agency: releases creative, uninhibited, innovative, entrepreneurial activism" (Sztompka, 1997). It is simultaneously a solution, towards a synthesis, to the theoretical dilemma of sociology, which can be reduced to the antinomy inherent in modernity: the "individualisation" or privatisation of risk, whose proper interpretative context and the causal source is the system level. It often concerns global conditions over which the individual has limited influence. Such an individual, based on socially acquired (reflexive) or cultural trust, is capable of cooperation and self-organisation, with a chance to maintain/recover a sense of agency.

From this point of view, the concept of social involvement or, in other words: "civic activism" is linked to the concept of trust. However, it is much more challenging to find an adequate or "canonical" conceptual platform here. Here, issues of the definition "depend on the perspective and interests of the definer" (Adler, Goggin, 2005, p. 238). The strong normativisation of the concept of engaging does not ease conceptualisation. However, it can be assumed that the key axis differentiating civic activism will be the distinction: informal/private or formal/ public (Adler, Goggin, 2005, p. 240), thus the mediation or lack of mediation of legitimate organisations. In each case, however, we are aware that this distinction is formal and does not consider a much broader group of activities, at the centre of which are questions of who is active and in which area, which means that we are dealing with a 'continuum of activism' rather than unconnected acts of involvement. There is also a lack of awareness of the diverse nature of activism and 
that 'activists' may divide their time between very different, parallel, more or less formal activities. The declaration of involvement in an organisation can therefore have a deeper indicative meaning.

While remaining aware of these conditions, we use a more neutral term (referring to the closer questions asked in the ESS editions) of civic involvement, meaning involvement in institutionalised forms of activity. At the operationalisation level, we will understand civic involvement as the declared undertaking of activity within organisations based on voluntary motivations, oriented towards the collective context of society. Both concepts of trust and social involvement are conceptually related. This relationship concerns both the impact of trust on declared involvement and social activism on the level of trust in society. Empirically verified observations may be easily interpreted based on individual and collective behaviours, taking the abovementioned understanding of Piotr Sztompka and his image of trust as a specific "social lubricant" as a basis. The question arises of how this 'lubricant' is produced and what determines its effectiveness and dissemination? Theoretical support for the formulation of similar questions is contained in the concept of social imponderables by the same author in the context of cultural trauma (Sztompka, 2004). In any case, the concept of trust is treated as one of the main elements of social cohesion. The conclusions from the research literature are not unequivocal, and it is worth pointing to the levels of criticism of direct linking of trust with involvement.

In line with the observed trends towards the rising levels of inequality and middle-class crisis:

- The level of trust can turn a downward trend (Putnam's thesis in Bowling alone, Putnam, 2000). Modernisation is therefore not a sufficient condition for an increase in the level of trust.

- Similarly, the proliferation of club-type organisations - based on market relations "may not forge enough common ground with others to generate trust at all" (Uslaner, Brown 2003, p. 5).

- The assumption of a direct link between 'engaging' and trust indicators is also inconvenient; the link is not straightforward (Uslaner, Brown, 2003, p. 6) or rejected outright (Petts, 2008). As Ingen and Bekkers elaborate: "be sure, we do not mean to say that civic engagement is unimportant; it means that we should start thinking about the relationship between trust and participation in a different way" (Ingen, Bekkers, 2015, p. 290). The relationship between specific types of trust from the perspective of the "recipient" of trust is a separate issue.

- One can see here a tendency to separate trust concerning different spheres of social functioning (e.g. confidence in political institutions or generalised trust), as illustrated by the Eurostat data on post-communist Europe quoted above.

It can be summarised that we know much more about how trust positively affects specific spheres of life; we know that people actively participating are more likely to 
be characterised by trust, but biographical or situational circumstances may influence this attitude. Much less is known about how to control the growth of trust on the level of society, apart from perhaps the widespread belief that we need to, for example, strengthen the non-governmental sector (Putnam, 2000; van Ingen, Bekkers, 2015). Van Ingen and Bekkers suggest that in terms of trust studies, "many issues remain unresolved in this line of research. One of those issues is that the causality of the relationship between trust and civic engagement has not been examined thoroughly" (van Ingen, Bekkers, 2015, p. 278). A similar comment can be made towards the relationship leading to civic engagement towards trust. Interpretations based on the logic of "path dependency" - that similar institutional-organisational conditions will lead to similar states of affairs - turn out to be insufficient (Stark, 1992). Especially while talking about low levels of trust, answers to questions about the rationale for increased confidence appear less noticeable. They require a deeper reflection, if only because "this raises the question of whether the experiences in voluntary associations are salient enough to change people's mental dispositions, which could be one of the reasons why spill-over effects are not often found" (van Ingen, Bekkers, 2015, p. 280). So, to what extent is civic participation, for example, a central issue in the social life of a particular society, involved in answering the question about the universality of involvement? The analysis needs to consider questions of the organisational origins and prevalence of cooperative traditions (Putnam, 1993). Whereby questions: what the trust is and who we trust require a reflection on the cultural and historical context of getting involved, and should take into account limitations of comparative analyses. What is, therefore, essential for us is to identify the correlation between trust and social involvement against the background of different conditions, in a temporal and situational perspective, which should also be understood as the influence of current politics or, e.g. natural events (including, e.g. pandemics).

\section{Cultural/Structural context}

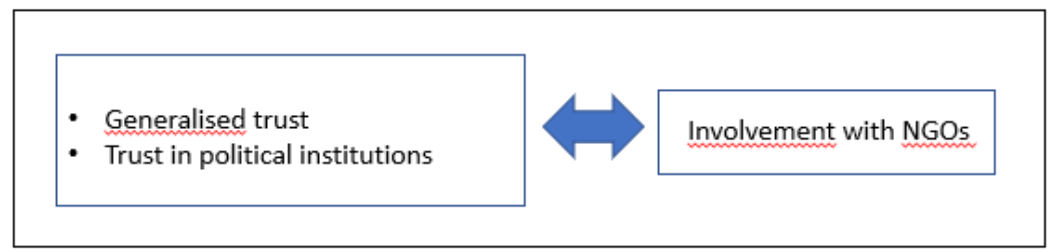

Increase in living standards through external influences

Source: Own elaboration

Figure 3: Schematic illustration of inference on trust and involvement in working for an organisation 
Elements of the Bulgarian and Polish case studies may be instructive, mainly due to differences in the perception of the systemic transformation process (Turk, 2014) and similar external influences affecting central and south eastern European societies (Podkaminer, 2013, Kipas, 2020). On the one hand, the research questions concern a comparative diagnosis of levels of trust and social involvement in the case of both societies. On the other hand, investigating the correlates of synthetic indicators of trust and activism in terms of sociodemographic variables at two points in time allows us to answer detailed hypotheses about the correlates of trust and the characteristics of those who 'engage'.

\section{The 2008 crisis. Not the only context for social change in Bulgaria and Poland}

The picture that emerges from interpreting Eurostat's public data using the GDP by PPS indicator reveals that over 10-15 years a significant increase in the quality of life has been recorded in almost all societies in the "new Union". On the other hand, some symptoms of stagnation could be registered in relation to the most developed European economies and societies (cf. chart on GDP by PPS for EURO Area, above). Bulgaria and Poland do not stand out against this background (except perhaps as a starting point, indicating a slightly lower standard of living in Bulgaria in 2008).

It is worth emphasising that the time analysed covers the time following the last great crisis in the world economy, symbolically linked to the collapse of the big investment banks, which undermined the post-war order initiated by the Bretton Woods Conference (1944). The fall of the Iron Curtain in central and south-eastern Europe (1989 - 1991) probably did not play a significant role in dynamizing the global evolution of societies. From a European perspective, it became the basis for the inclusion of previously peripheral areas into the system of socio-economic interdependence. The European integration process was enhanced by the accession of first Poland (2004) and then Bulgaria (2007) to the EU structures. In a sense, therefore, the histories of both societies constitute case studies of modernisation in post-crisis conditions, observed not from the perspective of participants in the global game (the centre of the world system), but of societies that have relatively recently become more autonomously part of the emerging global division of labour.

Both countries underwent simultaneously:

1. processes of implementation of European Union law (which often meant changing the rules of the game);

2. changes towards subsidiarisation and rescaling (which increased regional inequalities, Kazepov, 2008); 
3. the democratisation of social relations (which has strengthened the importance of minority groups with an initially marginal status).

Therefore, it is no coincidence that the mentioned phenomena, more than in other European societies, can be described in terms of mass 'learning' or imitation (Ziółkowski, 1999; Krastev, Holms, 2018). This suggests reactivity and symptoms of (new) identity formation in a clash between the internal and universal. Perfect examples are, e.g. EU environmental policies, equality policies, or the aidsupported development of the non-governmental sector (NGO, Chimiak, 2016; Domiter, Marciszewska, 2018) etc.

It can be assumed as a hypothesis that the exogeneity of the dominant influences mentioned above affected the basic indicators of the condition of societies, also from the point of view of an organisation and social self-organisation. On the other hand, the internal factors of social dynamism were eroded. In Poland, in the first decade of the new millennium, this meant, for example, a progressing crisis of self-organisation related to trade unions, or more broadly, a crisis of the party system. To some extent, it also meant a shift, typical of the second decade of the new millennium and more specific for the region, of the central axis of divisions: from historical divisions (based, for example, on the attitude to communism), class divisions (according to the division into the right and the left), or ethnic divisions, to the issue of the attitude to exogamous changes. This phenomenon, as we know, also has a universal character; although, at the same time, it is conceptualised differently, with a particular awareness of differentiation (Hutter, Kriesi, 2019). The Bulgarian case differs particularly from the Polish one in a certain diachronicity in terms of the process of marketisation, which was less dynamic in the first period of transition in the early 1990s and was associated with at least two deep crises triggering massive forms of contestation, the first ten years before depression in 2008 (in 1997) and the second two years after the explosion of social movements elsewhere (2013). Similar dynamics are difficult to find in the case of Poland.

\section{The second decade of the new millennium: dynamics in Bulgaria and Poland}

Analysing the literature of the topic, the beginning of the second decade of the new millennium is quite unambiguously associated with the emergence and development of the Occupy Movement in the countries of southern and western Europe (Lubin, 2012). In central and south-eastern Europe, however, it is difficult to find clear analogies with the events following a causal relationship with the global crisis of 2008. There is much to suggest that acts of disobedience in this part of Europe are sometimes placed in an 'Occupy context' (Hallberg, Ossewaarde, 
2016) due to an affinity rooted in temporal coincidence or the spread of a so-called "protest culture" during a similar period. Paradoxically, in terms of economics, these relations to the external environment (global crisis) have not worked to a similar degree. In the case of Poland, the same crisis that triggered the Occupy Movement "on the west" turned out to be more of an opportunity than a threat. This particularity of Central and Eastern (CEE) and South Eastern European (SEE) countries could be a direct consequence of regional specificity or a kind of rent or handicap resulting from "underdevelopment". From the perspective of $2008-2016$, this thesis can be defended by analysing, for example, the attitude of various forms of social self-organisation to democracy, neoliberalism or directly to the market economy, which maintains a decidedly less critical attitude. Forms of civic activity tend to emphasise collective and individual subjectivity, transparency of the public sphere and the quality of public authority management which can be simplistically described as Europeanisation. These phenomena did not take only an affirmative form, but were always perceived in terms of causality. The literature contains both references to populist and nativist political movements, which have historical origins in the dynamics of growing social inequalities accompanying privatisation and globalisation (Lindner, Novokmet, Piketty, Zawisza, 2020; Kipas, 2020).

\section{The case of Bulgaria}

The starting point of the history of Bulgaria's contemporary social dynamics seems to be 1997, which made its mark in Bulgarian history as a time of great economic and social collapse. In just a few months, more than a dozen banks went bankrupt, and inflation turned into hyperinflation at 300\% (Toteva, 2019). In a way, it was a harbinger of the crisis that followed 10 years later on a global level. Waves of protests swept through the country - roads, streets and entire cities were blocked, workers walked away from their jobs - chaos and nationwide grief ensued. In the post-millennium period, that is seven years before the Republic of Bulgaria joined the European Union, gradual economic growth began, and by the end of 2000 it was the highest in ten years. The country was waking up after the crisis of 1997 and the so-called January events, and more and more new enterprises and investments in infrastructure began to appear, which created new jobs. This period is also associated with the emergence of the non-governmental sector. The lack of practice in this field, as well as the lack of relevant sources and literature, plus the complicated process of registering NGOs meant that organizations were established rather slowly and interest in their statutory objectives was negligible (Pozharevska, 2005). Based on a survey carried out at the end of 2001, the NGO sector surveyed 259 organizations, the vast majority of which had tasks related to education and information in their statutory objectives. At the end of 2017, 
it was said that there were 785 actively operating organizations in Bulgaria, of which also the majority are related to the educational sphere (Stoychev, Zahariev, Yordanov, Markova, Dimitrova, 2017).

After the 1997 demonstrations, the next significant wave of protests were the events of 2013, which also triggered a broad socio-political crisis in the country. The immediate cause of the mass protests was significant price increases in electricity and gas fee (in most Bulgarian households most appliances, including heating, are powered by electricity). As a result of the demonstrations, the then incumbent government of Boyko Borisov quickly resigned. The dynamics of the events suggested a low level of trust towards political institutions; on the other hand, there was a clear increase in public involvement, especially of representatives of younger generations (Dabrowski, 2013), and protests were also visible on social media. It is estimated that up to one hundred thousand people took part in demonstrations. The causes of the crisis are attributed to the socioeconomic model of the time, the influence of the oligarchs on its functioning, the increase in the cost of living (electricity and gas bills), the visible problem with corruption, the impoverishment of society (about $22 \%$ of the population lived below the poverty line), and social inequalities visible to the naked eye.

When it comes to the organizational dimension of social self-organization, at the end of the second decade of the 21st century, it is still believed that NGOs in Bulgaria are the least recognized and known in general, organizations among all national institutions. A survey conducted by the capital's Open Society Institute in 2018 showed that $32.5 \%$ of respondents do not have an opinion about NGOs, $16.6 \%$ believe that NGOs do not fulfil their statutory goals, and about $30 \%$ of respondents do not trust them. $20 \%$ of respondents trust them, $3.5 \%$ of which trust them completely (Stoychev, Zahariev, Belcheva, Braynova, 2018).

There is a clear disproportion between grass-roots initiatives and pro-social education, which stimulates local action and activates the community. There is more and more talk of various foundations or associations which operate, for example, for charitable or environmental purposes, but many of them are wellknown international organizations with national branches. As it seems, the Polish example brings with it a significant qualitative difference.

\section{The Polish case}

In Poland, the beginning of the new millennium is sometimes referred to as "social un-movement" (Nowak, Nowosielski, 2006), i.e. an apparent weakening of the grassroots dynamics of civic activity and the dynamics of political manifestations, which is also connected, quite paradoxically, with the worsening economic situation and rising unemployment. In the period preceding Poland's accession to the EU, unemployment exceeded $20 \%$ (the rate for young people 
was even higher), and the so-called old social movements, including trade unions, were weakening. The social dynamics of Poland and Bulgaria were therefore significantly different, and the social upheaval that occurred in Bulgaria in 1997 had no parallel in the recent history of the Polish society. However, the differences appear to be deeper and go back to the specifics of systemic transformation models and the effectiveness of marketization strategies. As paradoxical as it may sound, the radical model of transformation implied a much lower level of social tension thereafter. One can also write about a certain level of stabilisation, which also included the already mentioned elements of social un-movement.

Indicators of a change in the trend in Poland became apparent towards the end of the first decade of the 21 st century $(2007-2008)$, when symptoms of revival appeared in the form of a growing sector of so-called urban movements, using the legal form of associations ${ }^{4}$.

They were distinguished by their protest potential (ability to self-organise in public space) and public visibility based on the Internet and growing social media. This was reflected in the evolution of the sphere of non-party politics at the level of big cities. In opposition to classical class conflict, these were primarily forms of dissatisfaction of the emerging middle class, drawing on previous experiences of civic protest inherited from the beginning of the 90s of the XX century (Pluciński, Nowak, 2017). Thus this was not a movement in direct response to the economic crisis and increasing unemployment, but rather a movement that can be seen as a response to the phenomenon of anomie (restriction of opportunities to express values and interests) that affected the middle segments of the urban social structure. The dominant motive of this movement was opposition to the growing investment activity of external actors and protests against the pro-investment and unsustainable policy of local authorities in the largest cities (Mergler, Pobłocki, Wudarski, 2013). These policies affected the interests of established, 'new' residents, which evokes the classic NIMBY syndrome (protests based on the slogan: Not in My Back Yard). They contested the pro-market and managerial model of community management. The movement, born in Poznań in 2008 as a protest against the city's spatial planning policy, can be mentioned as an example. At the declarative level and the level of social movement practice (election slogans in local government elections), reference was made to the ideology of Europeanisation. The neoliberal vision of systemic transformation was not questioned. These slogans were an expression of the expectation of the subjectivity of citizens or the will to revitalise cities as subjects rather than objects of politics. It avoided formulating demands for radical change, e.g. in the sphere of redistribution, protection of residents or recognition of minorities.

4 Cały sektor organizacji o podobnym pozarządowy w Polsce to 101 tys. organizacji (2018).

Z czego tzw. ruchy miejskie stanowiły baz wątpienia mniejszość. 
The understanding of the slogan "right to the city" (crucial for the articulation of the movement at the global level, Lefebvre 1996) was far from its folk or proletarian origins, which can be attributed to the cultural specificity of the activists themselves (Nowak, 2020). One can write about a specific selectivity of postulates, inscribed in the mentality of the metropolitan 'new middle class', looking for analogies with phenomena observed in the 1980s and 1990s in Canada (Ley, 1994) and other countries of the developed West. This led to a discussion about the movement's identity and the tendency for the middle-class appropriation of protest (Pluciński, 2020). However, this did not prevent the ideology of a similarly interpreted "right to the city" from becoming the seed of nationwide self-organisation (2010-) and the emergence of a functioning umbrella organization (Congress of Urban Movements). It organized annual congresses and carried out ongoing support activities for urban associative organisations in Poland (Jacobsson, 2015; Vargas-Tetmajer, 2016; Domaradzka, Wijkstrom, 2016). The organization thus evolved from a local NIMBY syndrome towards a form of umbrella cooperation, became part of the communication civil society infrastructure and a tool for political pressure.

A certain weakening of the importance and dynamics of urban movements occurred in the second half of the second decade of the new millennium (2015-). After eight years of government by the Liberals and the Peasant Party (Civic Platform, Polish Peasants' Party), the United Right came to power after the elections with its distinctly conservative, Christian and centralist vision of governance. Subsequent steps of the new government were met with growing protests from circles of the metropolitan intelligentsia, sympathetic to the liberal opposition, and the women's movement, the emergence of which was connected to the protest against changes in abortion law (from 2016). These protests were limited in scope and coordinated by the Committee for the Defence of Democracy at the first stage. During cyclical demonstrations, they brought together established professionals (usually elderly), supported by urban regimes linked to parties that had lost power. This changed when feminist movements joined the contestation (Kubisa, Wojnicka, 2018). On 3 October 2016, assemblies took place in 147 Polish cities under 'Black Monday/National Women's Strike'. The age of the protesters became pluralised, and the protests entered a mass phase, which exacerbated the marginalisation of other forms of social engagement at the community level.

In a sense, at this first stage of the articulation of protests, civic empowerment, and indirectly also trust, was again transferred from local communities to national ones. Along with demands to abandon judicial and social policy reforms (a significant extension of family benefits) and to maintain the consensus from the 1990s on abortion law, it became part of a national conflict rooted in the tension 
between the Christian and conservative (or if one prefers populist) and liberalpeasant visions of development. Its dynamics remained constant and dominated public discourse until the date of preparation of this text.

A significant proportion of urban activists (which is related to the elitist nature of participation, typical of Polish society, Nowak, 2020) became involved in the political-party protest, contributing to the marginalisation of local issues. At the next stage, the problems of minority groups (including the discussion on the legal status of LGBT+ communities) and forms of contestation of subsequent government policies gained importance.

In the case of Bulgaria, the turn of social dynamics seems to be the opposite (from a national to a local perspective). The evolutionary dynamics of economies are also clearly different, which seems relevant to the concept of trust. On the basis of the proposed interpretative framework, we turn to the analysis of data from the European Social Survey.

\section{The impact of generalised trust and trust in political institutions on the participation index in Bulgaria and Poland through the prism of the European Social Survey (2008 vs 2018)}

Our empirical analyses use Bulgarian and Polish data from the European Social Survey (ESS, rounds 4 and 9), a well-regarded cross-national comparative survey conducted biennially since 2002 . The ESS puts a strong emphasis on the standardisation of sampling and fieldwork procedures in a way that would enable cross-national comparisons of results (Fitzgerald and Jowell, 2010). Interviews are conducted face-to-face by trained interviewers, with individuals 15 years and older living in private households within country borders, irrespective of nationality, citizenship, language, or legal status (Lynn et al., 2007).

\section{Dependent variable (index of participation)}

The European Social Survey measures political participation by asking respondents several questions indicating undertaking by their different activities. The questions are as follows: "There are different ways of trying to improve things in [a country] or help prevent things from going wrong. During the last 12 months, have you done any of the following? Have you:
a) contacted a politician, government or local government official;
b) contacted politician or government official in the last 12 months;
c) worked in political party or action group in the last 12 months;
d) worked in another organization or association in the last 12 months;
e) worn or displayed campaign badge/sticker in the last 12 months;
f) signed petition in the last 12 months; 
g) taken part in lawful public demonstration in the last 12 months;

h) boycotted certain products in the last 12 months".

We have constructed an index of participation by counting how many activities were undertaken by each respondent.

\section{Covariates and factors}

Two of the main independent variables in our empirical model measure trust. Firstly, we included an index of generalized trust (social trust) as an average of three items, asking respondents to agree with the following statements using the scale range from 0 to 10 :

1. Either most people can be trusted, or you cannot be too careful in dealing with people (where 10 meant "Most people can be trusted");

2. Either most people try to take advantage of you, or they try to be fair (where 10 meant "Most people try to be fair");

3. Most of the time people are either helpful or are mainly looking out for themselves (where 10 meant "People mostly try to be helpful").

We also included the index of trust in political institutions as a mean value of items asking respondents whether they trust in the following institutions: country's parliament, the legal system, the police, politicians, and political parties (scale format range from 0 - No trust at all, to 10 - Completely trust).

We based our scheme on essential sociodemographic characteristics: gender, age, education level and domicile. Gender is coded as 0 (women) and 1 (men), while the exact age is calculated based on the differences between the survey period and the year of births. Education was measured in the ESS using the International Standard Classification of Education (ISCED) categories and recoded into four levels: less than lower secondary - ISCED 0-1; lower-secondary education completed - ISCED 2; upper-secondary education completed - ISCED 3; post-secondary non-tertiary education completed, and tertiary education completed - ISCED 4-6 (a reference category). We also included a domicile description by indicating three different types, i.e., country village, small town, and large town or outskirt of a big city (reference category).

\section{Results}

Table 1 presents the impact of generalised trust, trust in political institutions, and sociodemographic variables on the participation index in Bulgaria and Poland. The analysis is based on linear regression (predicting the values of the participation index), conducted separately for Bulgarian and Polish datasets. We used all the covariates and factors as independent variables. We included 
the technical variable (ESS round) to control the effect of time on the index of participation in both countries.

Table 1: Impact of generalised trust and trust in political institutions on the participation index in Bulgaria and Poland - ESS rounds 4 and 9

\begin{tabular}{|c|c|c|c|c|c|c|c|c|}
\hline \multirow{2}{*}{$\begin{array}{c}\text { Covariates and control } \\
\text { factors }\end{array}$} & \multicolumn{4}{|c|}{ Bulgaria } & \multicolumn{4}{|c|}{ Poland } \\
\hline & B & SE & t-test & $\mathrm{p}$-value & B & SE & t-test & p-value \\
\hline Intercept & .369 & .048 & 7.77 & .000 & .549 & .085 & 6.49 & .000 \\
\hline ESS round 9/2018 & -.109 & .023 & -4.75 & .000 & .169 & .037 & 4.57 & .000 \\
\hline ESS round 4/2008 & \multicolumn{4}{|c|}{ ref. } & \multicolumn{4}{|c|}{ ref. } \\
\hline Gender $($ Male $=1)$ & .111 & .023 & 4.94 & .000 & .142 & .036 & 4.01 & .000 \\
\hline Age of respondent & .000 & .001 & -.68 & .497 & .001 & .001 & .58 & .563 \\
\hline $\begin{array}{l}\text { Education level } \\
\text { (ISCED 0-1) }\end{array}$ & -.384 & .052 & -7.36 & .000 & -.697 & .141 & -4.96 & .000 \\
\hline $\begin{array}{l}\text { Education level } \\
\text { (ISCED 2) }\end{array}$ & -.340 & .036 & -9.39 & .000 & -.664 & .049 & -13.52 & .000 \\
\hline $\begin{array}{l}\text { Education level } \\
\text { (ISCED 3) }\end{array}$ & -.225 & .030 & -7.52 & .000 & -.466 & .045 & -10.31 & .000 \\
\hline $\begin{array}{l}\text { Education level } \\
\text { (ISCED 4-6) }\end{array}$ & \multicolumn{4}{|c|}{ ref. } & \multicolumn{4}{|c|}{ ref. } \\
\hline $\begin{array}{l}\text { Domicile } \\
\text { (Country village) }\end{array}$ & -.050 & .028 & -1.77 & .078 & -.094 & .046 & -2.07 & .038 \\
\hline $\begin{array}{l}\text { Domicile } \\
\text { (Small town) }\end{array}$ & .017 & .029 & .60 & .551 & -.058 & .046 & -1.26 & .207 \\
\hline $\begin{array}{l}\text { Domicile } \\
\text { (Large town or outskirt) }\end{array}$ & \multicolumn{4}{|c|}{ ref. } & \multicolumn{4}{|c|}{ ref. } \\
\hline Generalised trust & .021 & .006 & 3.62 & .000 & .018 & .010 & 1.80 & .072 \\
\hline Trust in political institutions & .015 & .006 & 2.68 & .007 & .028 & .010 & 2.75 & .006 \\
\hline
\end{tabular}

Note: Sample sizes: BG_2008 (N=2,230), BG_2018 ( $=2$,198), PL_2008 $(\mathrm{N}=1,619)$, PL_2018 (N=1,500).

Source: Own analysis based on ESS data.

As can be seen in the table, both generalised trust (trust in others) and trust in political institutions are significant (at p-level equal to 0.1) predictors of the participation index in Bulgaria and Poland. The impact of both covariates is positive, which means that the more the respondents trust others and trust in political institutions, the more active they are in the public sphere. One can also note that the impact of sociodemographic variables on the participation index is very similar in both countries. Male respondents are significantly more active, while those less educated (compared to respondents with the highest level of 
education) and people living in the country (compared to those living in big towns or at the outskirts of large cities) are less willing to participate. The significant differences between Bulgaria and Poland concern the effect of time. While in the case of Bulgaria, a substantial reduction in participation can be noticed over the decade $2008-2018$, there was a significant increase in participation over the same period in Poland.

\section{Summary}

In conclusion, the proposed perspective verified the relationship between trust indicators and declared involvement in NGO sector organisations and essential sociodemographic variables in a temporal perspective. ESS data was used for the analysis. Operationally, the basis for inference was the indices of "generalised trust", "trust in national political institutions", and "civic involvement" using Multilevel Regression Analysis. The analysis allowed, on the ground of the ESS, to verify the current state of research once again. On the other hand, it allowed, at the level of interpretation of the temporal context, to answer questions concerning the relation of a specific type of developmental processes (systemic transformation and global crisis) to the mentioned relations, assuming that cultural factors may be of particular importance. The interpretative background was based almost entirely on the research from the 1990s and the first decade of the new millennium, which indicates that we are dealing with an issue no longer at the centre of social science, but this does not mean that we know everything about trust. What we do not know concerns the specificity of the social context of which the trust is a 'product'. In the case studied, the specificity of the social process was clearly related to a particular variant of the process of social modernization, concerning post-communist Europe. Elements of these changes were clearly exogamous in character, which influenced the level of trust. The relative longevity of the level of generalized trust in time suggests its association with the cultural conditions of individual societies (which in turn remain an element of persistence rather than change), which of course does not mean that the level of trust is unchangeable.

The secondary analysis of data suggests clear similarities in the correlates of trust in Bulgaria and Poland. Social engagement is more often associated with higher levels of trust, the mediating variable here being level of education, albeit one should be cautious in this respect. Although the involvement scheme implies a certain level of social capital (the term is sometimes used in connection with trust), pro-social activity itself, e.g. at the local level and in towns, may take place without the mediation of organizations, or e.g. through confessional institutions (not included in the NGO sector). This makes it more research elusive. What seems to be the key interpretation of the presented analysis results concerns the 
specificity of forms of social self-organization in both countries. We are inclined to attribute the chronological increase in the level of trust in the case of Poland (and the lack of such increase in the example of Bulgaria) to the internal dynamics of the development of forms of self-organization. Thus, the evolution of self-organization forms of the middle segments of the social structure in big cities was an indicator of change. At the same time, the very phenomenon of this form of self-organization was rather a signal of deeper processes that take place at the level of the so-called social imponderables. They are therefore an element of the cultural perspective. At their center is the formation of a recognized area of involvement, independent from current social and political processes. Of course, this observation sounds trivial on the grounds of Sztompka's position. One could suggest though that on the basis of this concept - and in the case of Poland - It is confirmed. The Bulgarian example challenges the thinking of increased levels of trust in terms of increased activity. It suggests that when analyzing the relationship between community involvement and trust more attention should be paid to the local context and the probably less formal nature of involvement. Protest and activism, which is in line with obvious intuition, does not necessarily mean an increase in trust. It may mean quite the opposite. The phenomena of delegitimization of the political system clearly occurring after 2015 in Poland and 2013 in Bulgaria may affect the level of trust and its correlates. As a result, the rise of generalized trust, trust in institutions and the question of involvement in organizations (recorded in social surveys, including the ESS) may have collided with the tendency to delegitimize public authorities and to indirectly delegitimize political parties in a democratic system based on representation. However, similar conclusions are the domain of subsequent analyses and questions. For example, those concerning the relationship between dynamic phenomena occurring at the level of legitimization of power and, to some extent, the autonomizing civic sphere.

\section{Sponsorship}

This work was supported by the regional conference "Trust and well-being in the Balkans", held on 30 September - 1 October, organized by the Bulgarian Sociological Association in collaboration with the national sociological associations of Romania, Serbia and Northern Macedonia, and with the financial support of the International Sociological Association.

\section{References}

Adler, R. P., Goggin, J. (2005). What Do We Mean By "Civic Engagement", Journal of Transformative Education Vol. 3 No. 3, pp. 236-253, DOI: $10.1177 / 1541344605276792$ 
Involvement and Trust in Poland and Bulgaria in Comparison with other European Societies

Beck, U. (1992). Risk Society: Towards a New Modernity, Translated by Ritter, M., London: Sage Publications.

Bylgarski Centyr za Nestopansko Pravo, Organizacii s nestopanska cel v Bylgaria, Sofia 2001, available at: http://www.benl.org/uploadfiles/documents/ pravna\%20ramka/ngosinbg.pdf.

Chimiak, G. (2016). The Growth of Non-Governmental Development Organisations in Poland and Their Cooperation with Polish Aid, Warszawa: Wydawnictwo IFiS PAN.

Dąbrowski, T. (2013). Kryzys społeczno-polityczny w Bułgarii, Analizy, available at: https://www.osw.waw.pl/pl/publikacje/analizy/2013-02-27/kryzys-spoleczno-polityczny-w-bulgarii.

Domaradzka, A., Wijkström, F. (2016). Game of the City Re-negotiated: the Polish Urban Re-generation Movement as an Emerging Actor in a Strategic Action Field, Polish Sociological Review 2016; 195(3), pp. 291-308.

Domiter, M., Marciszewska, A. (2018). Trzeci sektor w Europie wobec deficytu demokratycznego w dobie integracji i globalizacji, Ekonomia XXI Wieku, 1(17), DOI: 10.15611/e21.2018.1.04.

Eurostat. (2013). Average rating of trust by domain, sex, age and educational attainment level [ILC_PW03\$DEFAULTVIEW].

Eurostat. (2021). GDP per capita in PPS, available at: https://ec.europa.eu/eurostat/databrowser/view/tec00114/default/table?lang=en

Gerard, H. F. (1991). Habermas' Concept of "Lifeworld", Systems Practice, Vol. 4, No. 6, pp. 547-563.

Hallberg, D. and Ossewaarde, M. (2016). Protest and Recognition in the Bulgarian Summer 2013 Movement, Protest, Social Movements and Global Democracy Since 2011: New Perspectives, Research in Social Movements, Conflicts and Change, Vol. 39, Emerald Group Publishing Limited, Bingley, pp. 85106. https://doi.org/10.1108/S0163-786X20160000039004

Hutter, S. \& Kriesi, H. (eds.). (2019). European Party Politics in Times of Crisis, Cambridge: Cambridge University Press, doi:10.1017/9781108652780

Fitzgerald, R. \& Jowell, R. (2010). Measurement equivalence in comparative surveys: the European Social Survey (ESS) - from design to implementation and beyond John Wiley \& Sons, New York, NY, USA, pp. 485-495.

Fullbrook, E. (ed.) (2003). The Crisis in Economics The post-autistic economics movement: the first 600 days, Routledge, London, New York.

Kazepov, Y. (2008). The subsidiarization of social policies: actors, processes and impacts, European Societies, 10:2, pp. 247-273, DOI: $10.1080 / 14616690701835337$

Kubisa, J., Wojnicka, K. (2018). Feminist movements in central and eastern Europe, Praktyka Teoretyczna Numer 4(30), DOI: 10.14746/prt.2018.4.0 
Lefebvre, H. (1996). The right to the city, in Kofman, E., Lebas, E. (eds.), Writings on cities, Cambridge, Massachusetts: Wiley-Blackwell.

Ley, D. (1994). Gentrification and the politics of the new middle class, Environment and Planning D: Society and Space, volume 12, pp. 15-74.

Lindner, A., Novokmet, F., Piketty, T., Zawisza, T. (2020). Political conflict, social inequality and electoral cleavages in Central-Eastern Europe, 1990-2018, World Inequality Lab - Working Paper No 25, available at: https://wid.worid/ wpcontent/uploads/2020/11/WorldinequalityLab_WP2020_25 ConflictinequalityCieavages_Central -EasternEurope.pdf

Lynn, P., Häder, S., Gabler, S., \& Laaksonen, S. (2007). Methods for achieving equivalence of samples in cross-national surveys: the European social survey experience, Journal of Official Statistics, 23(1), 107.

Inglehart, R. (2007). Postmaterialist Values and the Shift from Survival to SelfExpression Values, The Oxford Handbook of Political Behavior, Ed. by Dalton, R. J. and Klingemann, H.D., DOI: 10.1093/oxfordhb/9780199270125.003.0012 Jacobsson, K. (2015). Introduction: The Development of Urban Movements in Central and Eastern Europe, K. Jacobsson (ed.), Urban Grassroots Movements in Central and Eastern Europe, published by Ashgate Publishing, available at: http://www.ashgate.com/isbn/9781472434463.

Kipas, M. (2020). The transition of Southeastern European societies towards civil democracy and market economy: problems and perspectives, Politique et sociétés à Chypre aujourd'hui 46.

Krastev, I., Holmes, S. (2018). Explaining Eastern Europe: Imitation and Its Discontents, Journal of Democracy, vol. 29 no. 3, 2018, pp. 117-128, Project MUSE, doi:10.1353/jo0d.2018.0049.

Lubin, J. (2012). The 'Occupy' Movement: Emerging Protest Forms and Contested Urban Spaces, Berkeley Planning Journal, Volume 25, pp. 184-197, DOI 10.5070/BP325111760

Matei, A., Apostu, D. C. (2013). Non-Governmental Organizations as Agents of Modernization: A Romanian Perspective, "Procedia - Social and Behavioral Sciences" 81, pp. 142-146, DOI: 10.1016/j.sbspro.2013.06.402

Mergler, L., Pobłocki, K., Wudarski, M. (2013). Anty-Bezradnik przestrzenny: prawo do miasta w działaniu, Biblioteka Res Publiki Nowej, Warszawa.

Newton, K., Zmerli, S. (2011). Three forms of trust and their association, European Political Science Review, 3:2, pp. 169-200 \& European Consortium for Political Research doi:10.1017/S1755773910000330

North, D. C. (1984). Transaction Costs, Institutions, and Economic History, Journal of Institutional and Theoretical Economics, Bd. 140, H. 1., The New Institutional Economics: A Symposium, pp. 7-17. 
Involvement and Trust in Poland and Bulgaria in Comparison with other European Societies

North, D. C. (1992). Transaction Costs, Institutions, and Economic Performance, Occasional Paper \# 30, San Francisco: International Center for Economic Growth, available at: https://pdf.usaid.gov/pdf_docs/PNABM255.pdf

Nowak, M., Nowosielski, M. (ed.) (2006). Czy społeczny bezruch ? O społeczeństwie obywatelskim i aktywności we współczesnej Polsce, Wydawnictwo Instytutu Zachodniego w Poznaniu, Poznań.

Nowak, M. (2020). The 'right to the city' on various scales. Society Register, 4(4), pp. 7-48. https://doi.org/10.14746/sr.2020.4.4.01

Petts, J. (2008). Public engagement to build trust: false hopes?, Journal of Risk Research Vol. 11, No. 6, pp. 821-835.

Pluciński, P. (2006). Społeczeństwa obywatelskiego koncepcja liryczna. Przyczynek, [w:] Czy społeczny bezruch? O społeczeństwie obywatelskim i aktywności we współczesnej Polsce, red. M. Nowak, M. Nowosielski, Instytut Zachodni, Poznań.

Pluciński, P., Nowak, M. (2017). E pluribus unum? Źródła i specyfika ruchów miejskich we współczesnej Polsce, Przegląd Socjologiczny, LXVI, 3, ss. 115-135.

Pluciński, P. (2020). 'Meeting of waters'? The complex landscape of the polish right to the city activis, Society Register, 4(4), pp. 105-128, https://doi. org/10.14746/sr.2020.4.4.05

Podkaminer, L. (2013). Development Patterns of Central and East European Countries (in the course of transition and following EU accession), Research Reports 388, available: https://wiiw.ac.at/development-patterns-of-centraland-east-european-countries-in-the-course-of-transition-and-following-euaccession-p-2985.html

Pozharevska, R. (2005). Organizaciite s nestopanska cel v procesa na prisyedinyavane kym evropeiskata obshtnost, available at: https://www.unwe.bg/uploads/ ResearchPapers/Research\%20Papers_vol1_2005_No6_R\%20Pojarevska.pdf Putnam, R. D. (1993). Making Democracy Work. Civic Traditions in Modern Italy, with R. Leonardi and R. Y. Nonett, Princeton University Press, Princeton, New Jersey.

Putnam, R. D. (2000). Bowling Alone, New York: Simon and Schuster.

Rothstein, B., Stolle, D. (2008). The State and Social Capital: An Institutional Theory of Generalized Trust, Comparative Politics, Vol. 40, Number 4, pp. 441-459(19), DOI: https://doi.org/10.5129/001041508X12911362383354

Stark, D. (1994). Path Dependence and Privatization Strategies in East Central Europe, East European Politics \& Societies 6(1), pp. 17-54, DOI: 10.1177/0888325492006001003

Stoychev, G., Zahariev, B., Yordanov, I., Markova, E., Dimitrova, R. (2017). Aktivnite nepravetelstveni organizacji v Bylgaria prez 2007 g., available at: https://csoleaders.frgi.bg/uploads/resursi/4.pdf. 
Stoychev, G., Zahariev, B., Belcheva, D., Braynova, P. (2018). Doverieto v nepravitelstvenite organizacji v Bylgaria, available at: https://osis.bg/wp-content/uploads/2019/03/2018_12_12-Trust-NPO-final.pdf.

Stukas, A. A., Snyder, M. (2016). Self-fulfilling prophecies, in Friedman, H. S. (ed), Encyclopedia of mental health, 2nd edition, San Diego, CA: Academic Press, Vol. 4, pp. 92-100.

Swidler, A. (1986). Culture in action: symbols and strategies, American Sociological Review, Vol. 51, pp. 273-286.

Sztompka, P. (1997). Trust, distrust and the paradox of democracy, WZB Discussion Paper, No. P 97-003, Wissenschaftszentrum Berlin für Sozialforschung (WZB), Berlin.

Sztompka, P. (2004). The Trauma of Social Change: A Case of Postcommunist Societies, in Alexander, J. C., Eyerman, R., Giesen, B., Smelser, N.J., Sztompka, P. (ed.), Cultural Trauma and Collective Identity, University of California Press, pp. 155-195.

Sztompka, P. (2006). Zaufanie: fundament społeczeństwa, Wydawnictwo Znak, Kraków.

Statistics Poland. (2020). The non-profit sector in 2018, Kraków-Warszawa, available at: https://stat.gov.pl/obszary-tematyczne/gospodarka-spoleczna-wolontariat/gospodarka-spoleczna-trzeci-sektor/sektor-non-profit-w-2018-roku,1,7.html Tilly, Ch. (2005). Trust and Rule, Cambridge Univ. Pres, Cambridge.

Toteva, P. (2019). Golemite krizi na prehoda: Videnovata zima i yanuarskite sybitya ot 1997 godina, [online] available at: https://www.flashnews.bg/golemite-krizi-na-prehoda-videnovata-zima-i-yanuarskite-sabitiya-ot-1997-godina/

Uslaner, E. M., Brown, M. (2003). Inequality, trust, and civic engagement, American Politics Research, Vol. 31 No. X, DOI: 10.1177/1532673X04271903

van Ingen, E., Bekkers, R. (2015). Generalized Trust Through Civic Engagement? Evidence from Five National Panel Studies, Political Psychology, Vol. 36, No. 3, Doi: 10.111 1/pops.12105

Vargas-Tetmajer, A. (2016). Urban movements in Poland - a short presentation, Urban Research \& Practice, 9:3, pp. 311-321, DOI: 10.1080/17535069.2016.1234593

Ziółkowski, M. (1999). O imitacyjnej modernizacji społeczeństwa polskiego, W: P. Sztompka (red.), Imponderabilia wielkiej zmiany. Mentalność, wartości i więzi społeczne czasów transformacji, Warszawa: PWN, ss. 38-64.

Turk, Ž. (2014). Central and Eastern Europe in transition: an unfinished process?, European View, pp. 1-10, DOI: 10.1007/s12290-014-0329-z, Springer Berlin Heidelberg. 